\title{
The evolving nature of the marketing-supply chain management interface in contemporary markets
}

\author{
Giuliano Noci \\ Department of Management Engineering, Politecnico di Milano, Milano, Italy
}

\begin{abstract}
Purpose

The purpose of this paper is to reshape and interpret the essence of marketing-supply chain management (M-SCM) interface in the glance of the dramatic changes occurring in competition and market relationships.

Design/methodology/approach

By reviewing relevant literature and analyzing evolutions in the different phases of the marketing funnel, the author develops an evolutionary pattern for M-SCM interface.
\end{abstract}

Findings

As the markets evolve to an always-on, service-dominant logic, being market-driving becomes a necessary condition, and as such marketing strategies must be capable of reconfiguring supply chains to reshape the value for customers. This implies a dramatic organizational change, even beyond mere technological issues.

Originality/value

The paper aims at setting some research directions for business process management and organizational patterns to govern M-SCM interface.

\section{Article}

In the business community, there is an overwhelming trend of technology - big data, digital devices and artificial intelligence - being used for any business and marketing strategy.

In reality, the humans are, and should be, still in the center of both back-end and frontend business operations. After years of dreaming of completely automatized production systems and supply chain, the smart manufacturing puts human back to the center, acknowledging that the (often tacit) knowledge on business processes is the key to their proper functioning (Seethamraju and Marianovic, 2009). The human centricity is even more evident in marketing. The consumers have certainly gained much more bargaining power compare to the past, as the result of disintermediation between individuals and brands, and the diffusion of social networking platforms (Kucuk and Krishnamurthy, 2007). The decision-making dynamics, however, remain complex and far from codified: scientific literature suggests that a large part of the purchase decisions derives from emotions, instead of being a result of rational reasoning on factors such as price (Bagozzi et al., 1999; Lerner et al., 2015).

This does not mean to deny the evidential fact that businesses are going through probably the most profound transformation in the recent industrial history (Vargo and 
Lusch, 2004). They need to set up important projects managing the changes. However, such transformation needs to take place in the right perspectives, in which digital technologies are extraordinarily important, yet purely instrumental.

In such perspectives, marketing should take a new role which is even more pervasive, building on two pillars.

In the first place, there is the central objective of strengthening brand equity. Today's consumers are facing decisional processes even more complex than those in the past: multiple touchpoints, offering varieties, and explosion of information with varying credibility. Thanks to just this consciousness, we can understand the (renewed) centrality of brand: the strength of a brand lies in its capacity of responding, with multichannel perspectives, to the needs of the consumers who navigate an increasingly intertwined market context (Tsai, 2005; Baxendale et al., 2015). As such, brand trust is paradoxically elevated that a brand becomes a relationship in which the value proposition of a business offers is more and more a combination of "what" and "how," responding to the consumers.

In the second place, there is the need of interpreting the purchase process under a new light. Businesses used to consider the phases of shopping controllable from both spatial (point-of-sales) and temporal (the classic marketing funnel) perspectives. The rise of everywhere and everytime commerce must bring a decisive change of view, which suggests that it is fundamental for marketing managers to exercise certain control over the phase in which the need of purchase emerges, rather than the spatially and temporally undefined activity of purchase itself (Baxendale et al., 2015). Note that it does not deny the importance of the physical contacts but emphasizes the specific and fundamental capacity of the physical contact points which could facilitate the consumers to experience the products through five senses, in a multichannel purchase process ( Hultén, 2011; Scott and Uncles, 2018).

As such, the necessity of a new action plan for businesses clearly emerges, in which businesses should be loyal to the consumers rather than demanding the consumers' loyalty. This requires intimacy and profound understanding of the customers, i.e., the data and information for qualifying and interpreting interests, behavior and actions/reactions of the individuals exposed to marketing stimuli (Hofacker et al., 2016; Hsu, 2017). Marketing, and the marketing machine, become a new business operation cycle which has the same relevance that the production has had for all manufacturing enterprises until today. The new value proposition combines the "what" offered by the business and the "how" it relates to the market over time. Under this framework, marketing becomes strategy, and vice versa. The change in the market requires profound transformation in the offer system and in the businesses, questioning models such as the ones proposed by Porter in the 1980s that have significantly influenced how businesses have defined their strategies until today (Barney, 2014). The shift of a business's competitive advantage toward the market raises several important implications that we will discuss here in order to clear some assumptions that are no longer fully in line with the competitive environment:

- Good marketing/strategy today no longer means to continuously adapt the offer to consumers' changing needs. In this respect, the business community must take into account two key aspects: take actions that could prevent the consumers from making a different purchase choice, by creating cumulative advantages that make the choice of a certain brand a habit (Kumar and 
Reinartz, 2016); and be able to proactively guide the consumers' desires, proposing products that no market research has identified to be desired by the market itself, i.e. adopting a market driving, rather than a market-driven approach (Kumar et al., 2000). This implies working on reshaping supply chain in order to reconfigure the essence of competition and the value for customers (Elg et al., 2012; Ghauri et al., 2016), and for this reason requires more dyadic and dynamic relationships between marketing and supply chain management (Juttner et al., 2007).

- Competing to win in the consumers' minds not only requires a superior product. A business wins when it manages to assert its own criteria of choice, in which its offerings excel and its brand identity is founded, in the evaluation process of the individuals (Kumar et al., 2000). In this way, the brand becomes synonym of this set of criteria, and the business goes beyond satisfying a market demand, but determines what the market desires.

- The products continue to be an important part of business processes to materialize the defined positioning. However, they do not represent the entire value proposition. The products are naturally enriched through levers such as communication and distribution, which qualifies the dimension of process in a value proposition (Kozlenkova et al., 2015).

- Technology and R\&D are certainly important determinants of a business' success, but they are not all that it takes. In fact, as seen in the so-called sharing economy and the network economy, they could be the subject to appropriation of the third-parties (Park, 2017). Therefore, it is important working on different dimensions capable of understanding the market and developing capacity of planning and promoting attractive experience for the target market.

In conclusion, the dual force transformation in the market changes not only the marketing that we know but the entire business. On one hand, digital transformation penetrates the systems of interaction; on the other hand, the functioning of human mind, emphasizing its emotional side, is assuming an absolutely vital position. The complexity of the context, multiplicity of stimuli, large-scale availability of information: all the new advances should drive the management to analyze with greater attention the interaction with consumers, and to question what are the new forms of value that could reduce costs and risks for consumers? In other words, a new value chain is required, in which marketing will make more and more important differences from competitive and managerial points of view.

Therefore, the evolution of the interface between marketing and supply chain management first lies in the organization, even before the process or technology, with increasing weight on the design and the deployment of an effective architecture of interactions with the market. Literature has investigated organizational issues both in marketing and supply chain management. For example, in the marketing literature, different organizational behaviors were discussed including customer orientation, competitor orientation, innovation orientation and internal/cost-orientation (Kohli and Jaworski, 1990; Day, 1994; Christensen and Bower, 1996). In supply chain management, organizational issues include inter-organizational factors, inter-

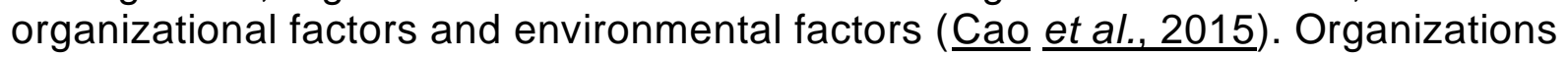
develop their capabilities, recruit and acquire resources, and plan activities according to their strategies (Olson et al., 2005). 
Literature, however, has not particularly investigated the organizational issues in the integration of marketing and supply chain management. As such, we warmly encourage research efforts on the inter-organizational dynamics for this interface, on matching the profiles of sales and engineering, on the capacity of collecting and sharing the market insights, including the emotional ones, and moving them upstream. Researchers may extend the previous studies of organizational issues of the two individual disciplines to their integration.

Such a focus is needed also because value innovation has been pointed out as an interactive, knowledge-generating process through which intra- and interorganizational relationships with supply chain empower the company's capability to operative and reshape their own market (Berghman et al., 2012; Sebastiao and Golicic, 2008). For this reason, we warmly encourage to deepen the essence and the success factors of this process, as well as the organizational conditions and contingencies fostering its efficiency and effectiveness, as a key to fully capture the value generation opportunities enabled by the current evolution of markets.

\section{References}

Bagozzi, R.P., Gopinath, M. and Nyer, P.U. (1999), "The role of emotions in marketing", Journal of the Academy of Marketing Science, Vol. 27 No. 2, pp. 184-206.

Barney, J.B. (2014), "How marketing scholars might help address issues in resourcebased theory", Journal of Academy of Marketing Science, Vol. 42 No. 1, pp. 24-26.

Baxendale, S., Macdonald, E.K. and Wilson, H.N. (2015), "The impact of different touchpoints on brand consideration”, Journal of Retailing, Vol. 91 No. 2, pp. 235-253.

Berghman, L., Matthyssens, P. and Vandenbempt, K. (2012), "Value innovation, deliberate learning mechanisms and information from supply chain partners", Industrial Marketing Management, Vol. 41 No. 1, pp. 27-39.

Cao, Z., Huo, B., Li, Y. and Zhao, X. (2015), "The impact of organizational culture on supply chain integration: a contingency and configuration approach", Supply Chain Management: An International Journal, Vol. 20 No. 1, pp. 24-41.

Christensen, C. and Bower, J. (1996), "Customer power, strategic investments, and the failure of leading firms", Strategic Management Journal, Vol. 17 No. 3, pp. 197218.

Day, G.S. (1994), "The capabilities of market-driven organizations", Journal of Marketing, Vol. 58 No. 4, pp. 37-52.

Elg, U., Deligonul, S.Z., Ghauri, P.N., Danis, W. and Tarnovskaya, V. (2012), "Marketdriving strategy implementation through global supplier relationships", Industrial Marketing Management, Vol. 41 No. 6, pp. 919-928.

Ghauri, P., Wang, F., Elg, U. and Rosendo-Rios, V. (2016), "Market driving strategies: beyond localization”, Journal of Business Research, Vol. 69 No. 12, pp. 5682-5693.

Hofacker, C.F., Malthouse, E.C. and Sultan, F. (2016), "Big data and consumer behavior: imminent opportunities", Journal of Consumer Marketing, Vol. 33 No. 2, pp. 89-97. 
Hsu, M. (2017), "Neuromarketing: inside the mind of the consumer", California Management Review, Vol. 59 No. 4, pp. 5-22.

Hultén, B. (2011), "Sensory marketing: the multi-sensory brand-experience concept", European Business Review, Vol. 23 No. 3, pp. 256-273.

Juttner, U., Christopher, M. and Baker, S. (2007), "Demand chain managementintegrating marketing and supply chain management", Industrial Marketing Management, Vol. 36 No. 3, pp. 377-392.

Kohli, A.K. and Jaworski, B.J. (1990), "Market orientation: the construct, research propositions, and managerial implications", Journal of Marketing, Vol. 54 No. 2, pp. 118.

Kozlenkova, I.V., Hult, T.M., Lund, D.J., Mena, J.A. and Kekec, P. (2015), "The role of marketing channels in supply chain management", Journal of Retailing, Vol. 91 No. 4, pp. 586-609.

Kucuk, S.U. and Krishnamurthy, S. (2007), "An analysis of consumer power on the internet”, Technovation, Vol. 27 Nos 1-2, pp. 47-56.

Kumar, V. and Reinartz, W. (2016), "Creating enduring customer value”, Journal of Marketing, Vol. 80, No. 6, pp. 36-68.

Kumar, N., Scheer, L. and Kotler, P. (2000), "From market driven to market driving", European Management Journal, Vol. 18 No. 2, pp. 129-142.

Lerner, J.S., Li, Y., Valdesolo, P. and Kassam, K.S. (2015), "Emotion and decision making", Annual Review of Psychology, Vol. 66, pp. 799-823.

Olson, E.M., Slater, S.F. and Hult, G.T. (2005), "Performance implications of fit among business strategy, marketing organization structure, and strategic behavior", Journal of Marketing, Vol. 69 No. 3, pp. 49-65.

Park, H.S. (2017), "Technology convergence, open innovation, and dynamic economy", Journal of Open Innovation: Technology, Market, and Complexity, Vol. 3 No. 4, pp. 24-36.

Scott, R.O. and Uncles, M.D. (2018), "Bringing sensory anthropology to consumer research", European Journal of Marketing, Vol. 52 Nos 1/2, pp. 302-327.

Sebastiao, H.J. and Golicic, S. (2008), "Supply chain strategy for nascent firms in emerging technology markets", Journal of Business Logistics, Vol. 29 No. 1, pp. 7591.

Seethamraju, R. and Marjanovic, O. (2009), "Role of process knowledge in business process improvement methodology: a case study", Business Process Management Journal, Vol. 15 No. 6, pp. 920-936.

Tsai, S.-p. (2005), "Utility, cultural symbolism and emotion: a comprehensive model of brand purchase value", International Journal of Research in Marketing, Vol. 22 No. 3, pp. 277-291. 
Vargo, S.L. and Lusch, R.F. (2004), "Evolving to a new dominant logic for marketing", Journal of Marketing, Vol. 68 No. 1, pp. 1-17.

This is an accepted manuscript of an article published in Business Process Management Journal, available online at: https://doi.org/10.1108/BPMJ-07-2018-0202 